\title{
PRKCA wt Allele
}

National Cancer Institute

\section{Source}

National Cancer Institute. PRKCA wt Allele. NCI Thesaurus. Code C51271.

Human PRKCA wild-type allele is located within 17q22-q23.2 and is approximately $508 \mathrm{~kb}$ in length. This allele, which encodes protein kinase $\mathrm{C}$ alpha type protein, is involved in the phosphorylation of diverse protein substrates in response to activation by calcium or the second messenger diacylglycerol. The PRKCA gene is overexpressed in certain types of cancer such as breast tumors, glioblastomas, pituitary tumors and thyroid neoplasms. 